\title{
Ferric/Ferrous Iron Contents of Garnet and Clinopyroxene and Calculated Oxygen Fugacities of Peridotite Xenoliths from the Eastern Finland Kimberlite Province
}

Woodland, A.B. ${ }^{1}$ and Peltonen, P. ${ }^{2}$

1. Mineralogisches Institut, Universität Heidelberg, Im Neuenheimer Feld 236, D-69120 Heidelberg, Germany (alan@classic.min.uni-heidelberg.de)

2. Geological Survey of Finland, P.O. Box 96, FIN-02151 Espoo, Finland (petri.peltonen@gsf.fi)

Upper mantle xenoliths were recovered from a kimberlite pipe in the Kaavi group of the Eastern Finland Kimberlite Province. The kimberlite bodies in this province intruded the late Archean craton during the early Paleozoic (450-600 Ma; Griffin et al., 1995; Peltonen et al., this volume). The pipe lies close to the suture zone between the late Archean craton and the adjacent Proterozoic $(\approx 1.9$ Ga.) Svecofennian mobile belt. The xenolith assemblage is dominated by garnet lherzolizes and harzburgites, with less common garnet-spinel harzburgites. Other rarer xenolith types include olivine websterites, wehrlites and eclogites with mantle affinities (Kukkonen and Peltonen, submitted). Some of the eclogites are diamond-bearing. Most of the peridotite xenoliths are hydrothermally altered to various degrees, with most olivine (ol) and orthopyroxene (opx) being completely replaced by low temperature phases such as serpentine. This hampers rigourous thermobarometric determinations for most samples. On the other hand, co-existing garnet (gt) and clinopyroxene (cpx) were unaffected by alteration so that equilibration temperatures can be estimated from this mineral pair. A minority of samples do contain relicts of orthopyroxene, also permitting an estimate of equilibration pressure.

The garnet-clinopyroxene thermometer of Krogh (1988) yields temperatures of $1100-1186^{\circ} \mathrm{C}$ for the garnet peridotites (at $5.0 \mathrm{GPa}$ ), the assumed pressure being based on results obtained from the few orthopyroxene-bearing samples. The garnet-spinel peridotites record lower temperatures of 830$1030^{\circ} \mathrm{C}$ (at $\left.3.0 \mathrm{GPa}\right)$. The spinels in these samples are anhedral and are only in contact with olivine, suggesting they are residual in nature. Therefore, the equilibration pressure for these samples could have been somewhat higher, although the observed low temperatures are more consistent with the transition from the spinel to garnet peridotite stability field being caused by a cooling event. The unavoidable uncertainty in pressure has only a small effect on the calculated temperature $( \pm 0.5 \mathrm{GPa}$ changes the calculated temperatures by $\approx \pm 20^{\circ}$ )

In an attempt to understand the redox conditions that existed in the upper mantle beneath the Fennoscandian Shield, we have measured the $\mathrm{Fe}^{3+} / \Sigma \mathrm{Fe}$ of garnet and clinopyroxene separates from the peridotite xenoliths by Mössbauer spectroscopy (at room temperature). Garnets in garnet-spinel peridotites have $\mathrm{Fe}^{3+} / \Sigma \mathrm{Fe}=0.02-0.03$, after correcting for recoil-free fraction effects (Woodland and Ross, 1994), and coexisting clinopyroxenes have $\mathrm{Fe}^{3+} / \Sigma \mathrm{Fe}=0.08-0.15$. In the garnet peridotites, garnet and clinopyroxene have higher $\mathrm{Fe}^{3+}$ contents: $\mathrm{Fe}^{3+} / \Sigma \mathrm{Fe}=0.06-0.10$ and $0.18-0.21$, respectively. Therefore, the $\mathrm{Fe}^{3+}$ contents in garnet increase with increasing temperature as observed by Luth et al. (1990) and Canil and O'Neill (1996). Calculation of the oxygen fugacity $\left(f \mathrm{O}_{2}\right)$ recorded in the samples is compromised by the lack of preserved olivine and orthopyroxene, which participate in the available calibrated oxygen barometers. However, the $\mathrm{X}_{\mathrm{Fe}}$ in the co-existing olivine and orthopyroxene can be approximated from the Mg-Fe exchange systematics of Brey and Köhler (1990) at a given temperature (given by the gt-cpx thermometer) and an assumed pressure of equilibration. Then, an estimate of the $\mathrm{fO}_{2}$ can be made using the equilibrium involving the skiagite component in garnet:

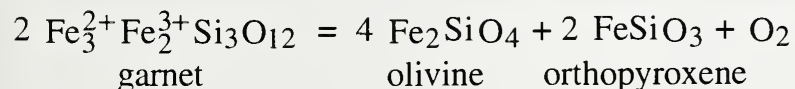


which has recently been experimentally calibrated by Gudmundsson and Wood (1995). This equilibrium has been shown to be subject to less error than other possible garnet-bearing equilibria involving the andradite component (Gudmundsson \& Wood 1995). The resulting $\Delta \log f \mathrm{O}_{2}$ values are $\approx$ FMQ-4.0 for the garnet-spinel peridotites xenoliths and FMQ-4.5 to FMQ-3.6 for the garnet peridotite xenoliths, which correspond to conditions $\approx 0.5$ to $1.5 \log$ units above the iron-wüstite oxygen buffer. These values are relatively insensitive to errors in the olivine and orthopyroxene compositions, with uncertainties in $\mathrm{X}_{\mathrm{Fe}}$ of $\pm 1 \mathrm{~mol} \%$ in these phases causing a shift of $\leq 0.4 \log$ units. In addition, two samples with relict orthopyroxene gave essentially the same result (within 0.2 $\log$ units) when the orthopyroxene composition was used and when the $\mathrm{X}_{\mathrm{Fe}}$ in orthopyroxene was estimated from the $\mathrm{Mg}$-Fe exchange systematics. Our results are comparable to values recalculated from literature data for garnet peridotite xenoliths from South African and Siberian kimberlites (e.g. Luth et al., 1990).

\section{References}

Brey, G.P., and Köhler, T., 1990, Geothermobarometry in four-phase lherzolites II. New thermobarometers, and practical assessment of existing thermobarometers: J. Petrol., v. 31, p. 13531378 .

Canil, D., and O'Neill, H.St.C., 1995, Distribution of ferric iron in some upper-mantle assemblages: J. Petrol., v. 37, p. 609-635.

Griffin, B.J., Rissanen,J., Pooley, G.D., Lee, D.C., Macdonald, I., and Kinny, P.D., 1995, A new diamondferous eclogite-bearing kimberlitic occurrence from Finland: Sixth International Kimberlite Conference Extended Abstracts, Novosibirsk, Russia, p. 198-200.

Gudmundsson, G., and Wood, B.J., 1995, Experimental tests of garnet peridotite oxygen barometry: Contrib. Mineral. Petrol., v. 119, p. 56-67.

Krogh, E.J., 1988, The garnet-clinopyroxene Fe-Mg-geothermometer - a reinterpretation of existing experimetnal data: Contrib. Mineral. Petrol., v. 99, p. 44-8.

Kukkonen, I.T., and Peltonen, P., 1998, Xenolith controlled geotherm for the central Fennoscandian Shield - Implications for lithosphere-asthenosphere relations: Tectonophysics, submitted.

Luth, R.W., Virgo, D., Boyd, F.R., and Wood, B.J., 1990, Ferric iron in mantle-derived garnets, implications for thermobarometry and for the oxidation state of the mantle: Contrib. Mineral. Petrol., v. 104 , p. $56-72$.

Woodland, A.B., and Ross, C.R., 1994, A crystallographic and Mössbauer spectroscopy study of $\mathrm{Fe}_{3} \mathrm{Al}_{2} \mathrm{Si}_{3} \mathrm{O}_{12}-\mathrm{Fe}_{3}^{2+} \mathrm{Fe}_{2}^{3+} \mathrm{Si}_{3} \mathrm{O}_{12}$ (almandine-skiagite) and $\mathrm{Ca}_{3} \mathrm{Fe}_{2}^{3+} \mathrm{Si}_{3} \mathrm{O}_{12}-\mathrm{Fe}_{3}^{2+} \mathrm{Fe}_{2}^{3+} \mathrm{Si}_{3} \mathrm{O}_{12}$ (andraditeskiagite) garnet solid solutions: Phys. Chem. Minerals, v. 21, p. 117-132. 